\title{
VAPB Gene Product
}

National Cancer Institute

\section{Source}

National Cancer Institute. VAPB Gene Product. NCI Thesaurus. Code C124937.

A protein encoded by the VAPB gene. 